\title{
Scientific, Educational, and Environmental Considerations Regarding Mine Sites and Geoheritage: A Perspective from SE Spain
}

\author{
Jose A. López-García • Roberto Oyarzun • \\ Sol López Andrés · Jose I. Manteca Martínez
}

\begin{abstract}
Should abandoned mine sites be eligible for søme •fficial protection under the umbrella of geconservation? Providing they have enough educational and scientific value, the answer is affirmative, and we suggest that they should be granted protection at the level of geoheritage sites. Some may see mining as an environmental disaster, but others, with a more geølogically oriented mind, may perceive mining as a blessing. Mining unveils the gelogy, thus allowing a more comprehensive vision of geølogical features such as rock units, faults, minerals, etc. We analyze the advantages and disadvantages of abandoned mines and districts as geølogic •bservational sites, through the analysis of two mining districts from SE Spain: Mazarrón and Cartagena-La Unión. We propose that if an abandoned mine site or district has enough geølogical

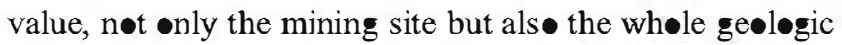
block hosting the ore deposits should alsø be protected. In this respect, the Sierra de Cartagena, hosting the CartagenaLa Unión district, is a valuable geological asset where an important chapter of the Alpine and late Alpine geølogic history of SE Spain is written.
\end{abstract}

Keywords SE Spain - Mine sites · Geøheritage · Mazarrón . Cartagena-La Unión

J. A. Løpez-García $(\square) \cdot \mathbf{R}$. Oyarzun · S. Løpez Andrés

Departamento de Cristalıgrafia y Mineralıgía,

Facultad de Ciencias Geølógicas, Universidad Complutense,

28040 Madrid, Spain

e-mail: jangel@gevucm.es

J. I. Manteca Martínez

Departament॰ de Ingeniería Minera, Geølógica y Cartográfica,

Universidad Politécnica de Cartagena,

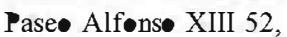

30203 Cartagena, Spain
Introduction

Abandoned mine sites and mining districts, providing they are important enøugh, may be granted the status of "site $\bullet$ cultural or historical heritage." However, it would be difficult to find many that are under consideration as geoheritage sites. Given the huge educational value of many $\bullet$ ld mines and districts, one may wonder why these sites are not adequate for geoheritage consideration. Peøple mined the planet for thousands of years, first to •btain stones for crucial activities such as hunting (e.g., •bsidian for arrowheads), or looked for minerals to paint in caves and røck walls (e.g., frøm hematite: red ॰chre, or limønite: yellow ochre), eventually extracting metals from minerals (e.g., copper from malachite). There is n๑ way to describe in a few words how important mining has been and continues to be for us. However, if mining is sø important for søciety, why then are mine sites usually excluded from the geølogic heritage? Perhaps, the roots of this misconception can be traced the classic compilation work of Sharples (2002), wh॰ prøpesed that:

Geoheritage comprises those elements of natural geodiversity which are of significant value to humans for non-depleting purposes which do not decrease their intrinsic or ecological values. The import of this definition is that it implies a distinction between the utilitarian resource values derived from the removal, processing or manipulation of rocks, landforms and soils by means such as mining, engineering or agriculture, and the conservation values of rocks, land forms and soils as heritage in their natural state.

In making a case for the treatment $\bullet \bullet$ ld mining sites as valuable contributors to geoheritage, it may help to consider an example. Let us take the case of the lead-silver Naica 
mine in Mexice, where exploration works revealed the existence $\mathrm{f}$ iant, faceted, and transparent single crystals of gypsum as lon as $11 \mathrm{~m}$ (Fi. 1) (García-Ruiz et al. 2007). This is net just a singular eddity, because a similar finding was recorded at the huge El Teniente mine in Chile, where 6-m-leng, 1.5-m-wide, gypsum crystals were found in caves formed within a breccia unit (Braden Formation) (Camus 1975). Mines are net just sites where the natural state of nature has been altered. Apart fiom econemic and therefore secial considerations, they play anther crucial rele: they urveil geolegical ebjects that under nermal circurnstances, n- ne weuld see. In this respect, ne may lıok at mine sites either as a problem or as an eppertunity. We examine both aspects in this work through the study of twe examples frem SE Spain: the Mazarron and Carngena La Union districts, both having a certain level of protection as "sites of cultural herimge" but lacking recegnition fiom the perspective of ecenservation.

\section{The Mazarrón and Carmgena-La Unión Districts: Unusual Geoløgical Scenaries}

\section{Peculiar Velcanic and Metallegenic Features}

The geelegy of SE Spain (Almería and Murcia regiens) is characterized by the presence of tw of the mest impertant Alpine complexes: Alpujarride and Nevado Filábrides. These units were intensively folded and thrust during the late Oligecene early Miecene, and they later underwent extensional collapse through majer dechment systems in the middle-late Miecene (e.8., Doblas and Oyarzun 1989; Platt and Vissers 1989). The latter episode was accompa-

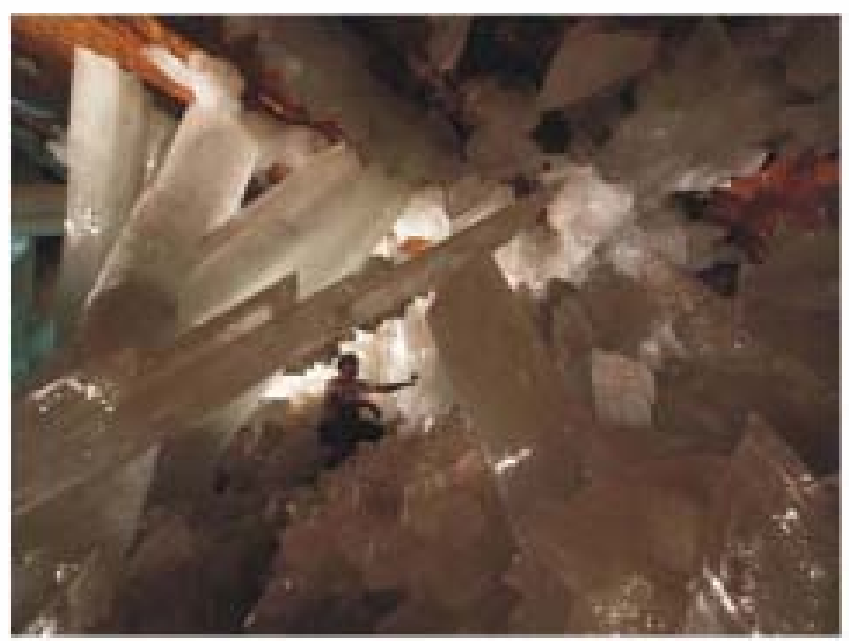

Fig. 1 Treasures unveiled by underground mining. Vlew of giant gypsum crystals (selenite variety) at the Naica $\mathrm{Pb}-\mathrm{Ag}$ mine. The crystals display wonderfully preserved prismatic crystal faces (GarcíaRuiz et al 2007). See miner for scale. Photograph: Javier TruebaMadrid Scientific Fims nied by impertant calc-alkaline to high calc-alkaline and sheshønitic velcanism (andesites, dacites, rhy lites) alent the Almería Cartagena velcanic belt (ACVB) (Fig. 2), whereas sedimentation took place within restricted matine sedimentary basins. The velcanism triggered hydrothermal activity that led the formation of impertant ore depesits - $\mathrm{Au}$ at Redalquilar (Almería) and $\mathrm{Pb}(\mathrm{A} \xi) \mathrm{Zn}$ and $\mathrm{Sn}$ at Carmena La Union (Oyarzun et al. 1995). This is a mest peculiar arrangement of velcanic series and ere depesit types, the whele eccurring within a shert and narrow belt of $\sim 160 \times 20 \mathrm{~km}$ between the lecalities of Almería and La Manga del Mar Mener (Fis. 2). We may find an equivalent metallegenic and velcanic scenarie in the Chilean Belivian Andes, but in that case, we are dealing with phenemena develeped at an immensely larger scale (Oyarzun et al. 1995). Furthermere, while the Andean velcanism is related to the subduction of the Nazca plate, in SE Spain, there is n- subluction, but the extensional collapse of the Alpine -regeny triggered the velcanic activity (Doblas and Oyarzun 1989; Oyarzun et al. 1995; Benite et al. 1999). Thus, the ACVB and asseciated re depesits can be regarded as a model-like, dwarfed representation of the velcanism and mewallegenesis fiem the Central Andes but that nonetheless formed through an entirely different plate tectenics scenarie (Oyarzun et al. 1995).

\section{The Mazarrón District}

The Mazarrón $\mathrm{Pb}(\mathrm{A} \mathbf{g})$ Zn mining district, inactive (Figs. 3 and 4a) (Redriguez and Hidalgo 1997; Arana 2007; Oyarzun et al. 2010), is lecated clese to the town of Mazarron, $4 \mathrm{~km}$ fiom the Mediterranean ceast in SE Spain. The site was mined, altheugh intermittently, since Reman times (200 BC to $300 \mathrm{AD}$ ) (Manteca Martinez et al. 2005). The Remans mined lead, and later working was for alum (aluminum sulfate: alunite) during the fifteenth to sixteenth centuries, then for the iron exide-rich alum wastes (the scalled almagres; 1774 1953), and finally for lead, silver, and zinc during the nineteenth to twentieth centuries (until the early 1960s) (Redriguez and Hidalge 1997; Manteca Martínez et al. 2005; Martínez Alcalde 2005). Velcanic activity ave rise to high-K calc-alkaline andesites, dacites, and rhy dacites of Tertonian to Messinian age that were emplaced as subvelcanic domes within a basement constituted by the Nevade Filábrides and Alpujárrides complexes (Fi. 3). Pyreclastic recks such as ashfall depesits are als present in the area. The velcanic recks form an inner ring within the herseshee structure buunding the Mazarron basin. The Mazarrón basin was infilled during Tertenian Messinian and Pliecene time by marine sediments comprising marls, sandstenes, conglemerates, and cequina limestenes (Fi 3). The district hests $\mathrm{Pb}$ ( $\mathrm{Ag}$ ) $\mathrm{Zn}$ epithermal depesits of the vein stockwerk type that were mined at 
Fig. 2 The Almería-Cartagena

volcanic belt $(A C V B)$ and main mine districts. Volcanic series after López Ruiz and R॰dríguez Badiøla (1980). Districts a fuer Oyarzun et al (1995) and Viladevall et al. (1999)

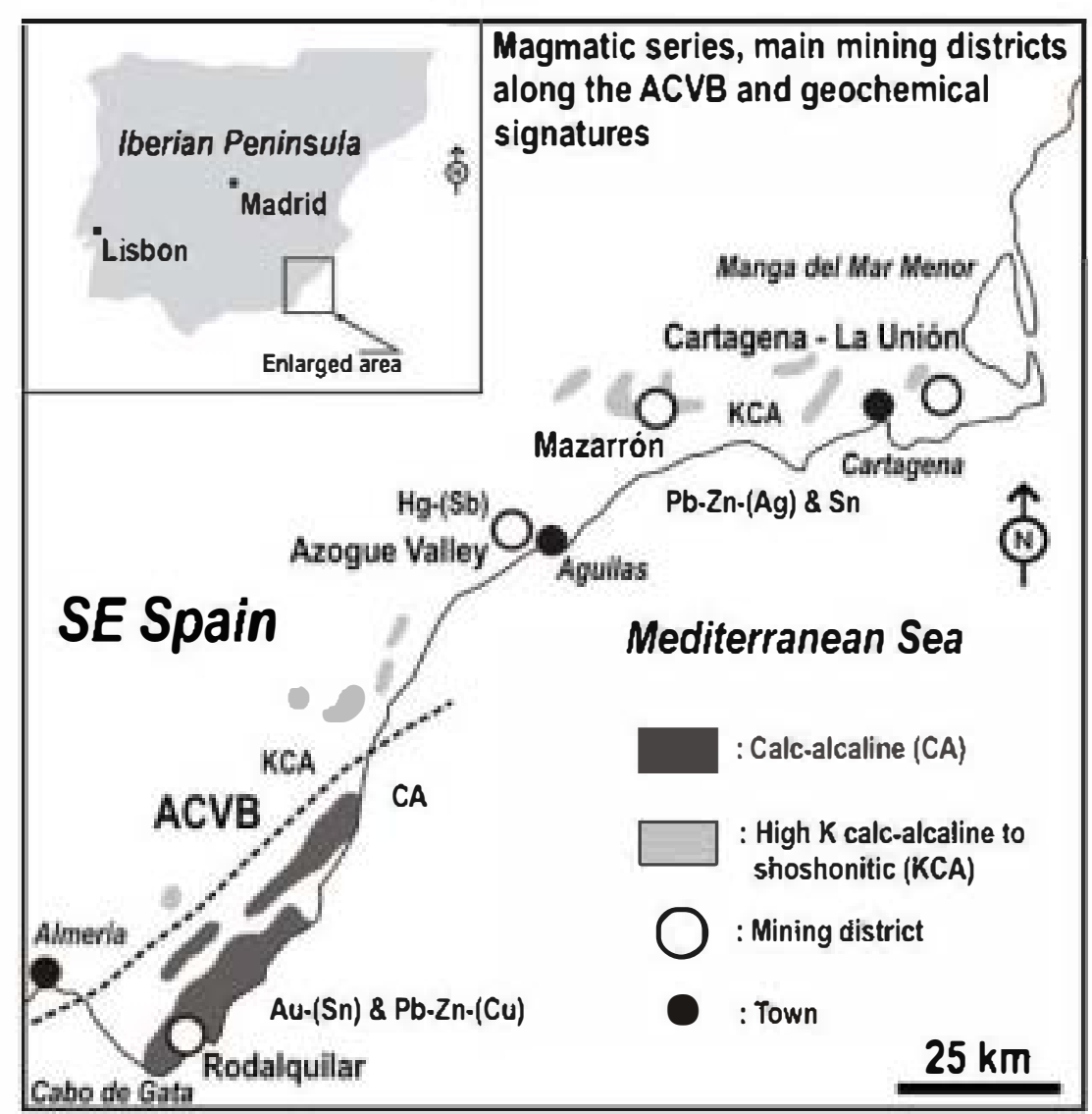

Cot• Fortuna, Pedreras Viejas, and San Crist bal Perules (Fiss. 3 and 4a). These sites are characterized by the presence of dacitic to rhy dacitic domes that underwent strong and pervasive advanced ar illic hydrethermal alteration, with formation of kaolinite, alunite, and silica. The main ore minerals are pyrite, sphalerite, and A-bearing
Ealena (up to $1520 \%$ A ), whereas $\bullet$ ther sulfides include chalcopyrite, tetrahedrite-tennantite, arsenopyrite, cinnabar, stibnite, and berthierite. Secondary minerals include cerusite, anglesite, smiths-nite, azurite, and malaquite, whereas zangue minerals include quartz, calcite, siderite, dolomite, and sypsưn (Arana 2007).

Fig. 3 Geølogy of the Mazarrón mining district indicating location - f main mine sites. NFA Nevad• Filábrides and Alpujarrides Complexes. Simplified after Oyarzun et al (2010)

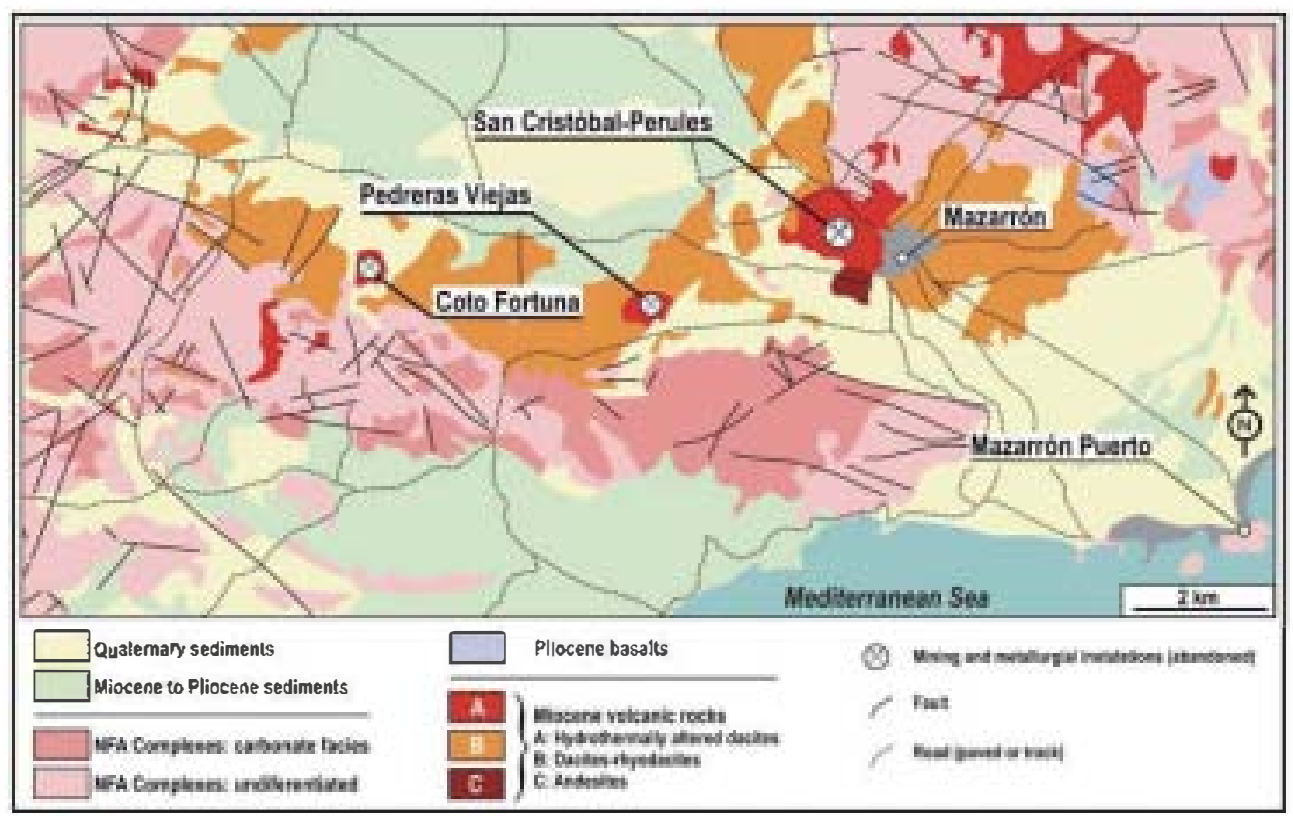




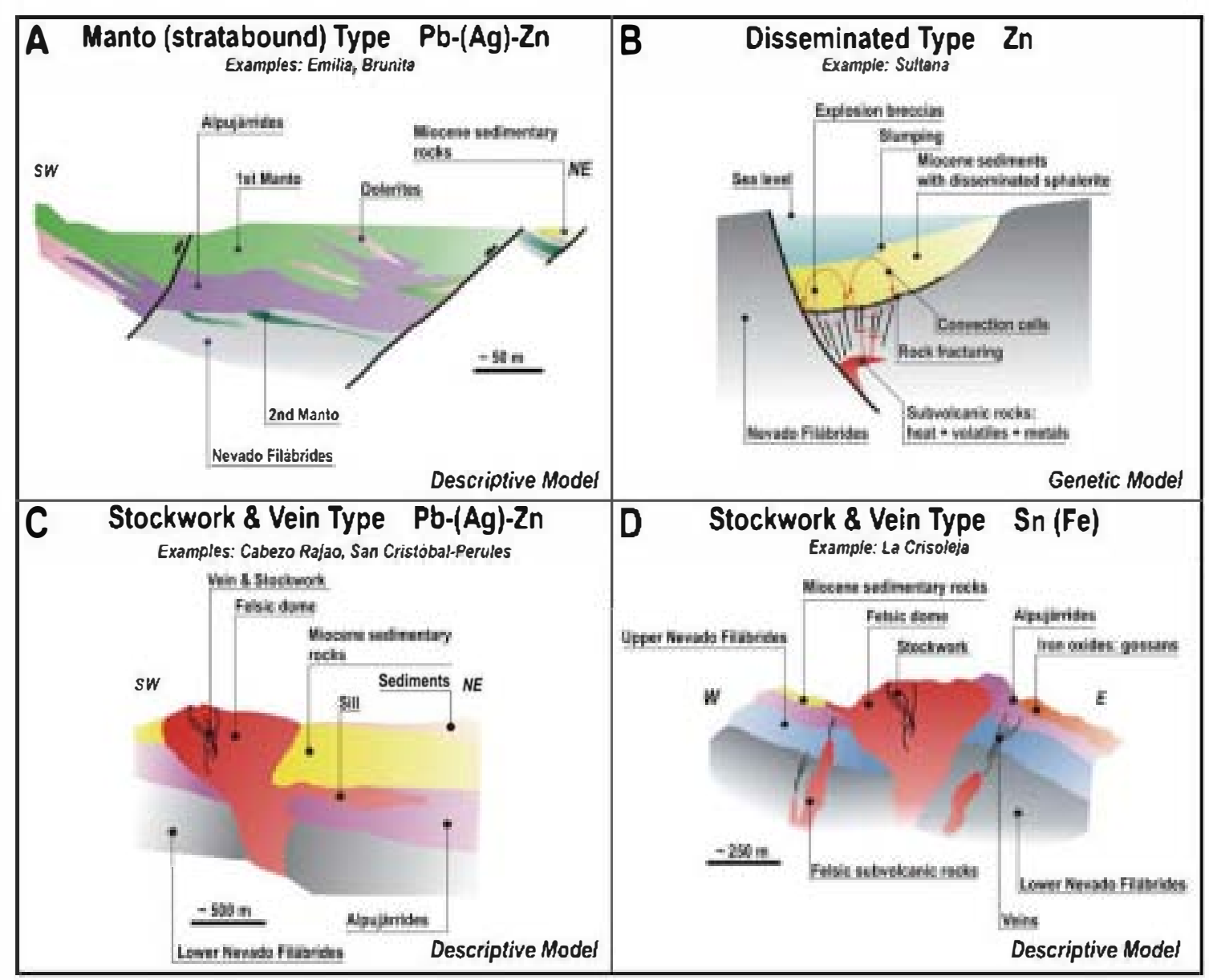

Fig. 6 Main ore deposit types from the Cartagena-La Unión district including San Cristóbal-Perules (Mazarón). Based on Manteca Martínez and Ovejer॰ Zapin॰ (1992)

tw distinct mineral assemblages: (a) greenalite magnetite sulfide carbonate silica and (b) chlorite sulfide carbonate silica. Most of the lead and zinc produced in the district were extracted firm these mant -type deposits. (2) Disseminations in the Miecene matine facies the best example is found at the Sulma mine, where the ore forns irregular bodies in the Miecene conglemerates and marls (Fis. 6b). This is a sphalerite-rich mineralization with pyrite, marcasite, and zalena as miner phases. (3) Veins these are tabular depesits that developed in highly fractured domains in the complexes and had little econemic impermince. (4) Stockworks in felsic domes such as these of Cabez• Raja• (Fis. 6c) and La Crisoleja (Figs. 4c and 6d). The ore bodies consist of complex stockwo zones with asseciated splay-mineralized veins. Alth un the Cabez• Raja mineralization is typically - $f$ the $\mathrm{Pb} \mathrm{Zn}$ type (Fis. 6c), at La Criseleja, there is a unique mineral assemblage tich in tin and exides (Figs. 4c and 6d). (5) Oxidation zones the near surface ore bodies underwent strong exidation processes that resulted in the formation of the s-called monteras (gossans) with a complex mineral $\bullet y$ -f -xides, sulfates, and native elements such as silver and copper (Lopez García et al. 1988).

\section{On the Educational and Secial Values of Mazarrón and Cartagena-La Unión}

Sharples (2002) suggested that geoheritage sites should be -f value to humans, providing scientific evidence of the past development of the Earth, constituting sites of importance for research and education, including features - f recreational or tourism significance, and having features that form the basis of landscapes that have contributed to the sense of place of particular hurnan communities. We believe that geological settings such as these of Mazarton and Cartagena La Union fulfill these conditions. B॰th districts are contined within a region with a unique geological history invelving (1) the buildup and final cellapse of an Alpine er geny (Betic Ranges); (2) vølcanism that led to generation of calc-alkaline to high-K calcalkaline and even sheshenitic velcanic series; and (3) the development of different styles of hydrothermal activity that ultimately led to formation a myriad of ore depesiv types (Fis. 6) and unusual mineral parageneses. In this respect, the following facts must be highlighted. The asseciation of greenalite magnetite with $\mathrm{Pb} \mathrm{Zn}$ ores in the 
mantø-type ore deposits from Cartagena-La Unión (Fig. 6a) cønstitutes a møst unusual case unknøwn anywhere else (@en et al. 1975). Besides, metallogenic clusters (groups •f genetically related ore deposits) are usually very simple, containing a single or two (at the most) ore deposit types. Cartagena-La Unión contains more than four fundamental types including stratabound, disseminated vein, and stockwork (Fig. 6). Furthermore, this account neither includes minor types nor the variety of metallic signatures $(\mathrm{Pb}, \mathrm{Zn}$, Ag, and Sn).

For these reasens, the Mazarrón and Cartagena-La Unión districts are privileged sites for research and education, and have provided the perfect gelogic-metallogenic scenario for numerøus research papers and doctoral theses. Besides, every year, these districts attract visiting lecturers and students of gelogical sciences from Spain and other Eurøpean countries. In terms of recreational or tourism significance, we must highlight the activity of the Tourist Consortium of the Sierra Minera (formed by the Autonomous Community of Murcia and the towns of Cartagena and La Unión), which carries •ut important actions to improve envirømental conditions while preserving the important mining heritage. The Consortium has developed heritage preservation projects such as those of Cueva Victoria, Ruta del 33, and the La Unión Mining Museum. The Ruta del 33 (The 33 Trail) is a particularly relevant educational project that consisted in rehabilitation -f an •ld mine trail crossing the Sierra de Cartagena from La Unión to Portman Bay (Fig. 5) (Manteca Martínez et al. 2008). The visitor can have access to old mine workings (e.g., the Agrupa Vicenta underground mine) and the local gelogy.

Finally, regarding Sharples's "landscapes that have contributed to the sense of place of particular human

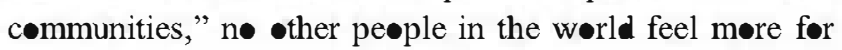
their places than miners, and this tradition remains strong at La Unión, where it gave rise 50 years age to a major annual musical festival, the s-called Cante de las Minas, representing the flamence history of the mining tradition (Fundación Cante de las Minas 2010).

\section{Environmental Pros and Cons}

\section{The Facts: Valuable but Pølluted Sites}

Despite the unquestionable educational and søcial values $\bullet$ Mazarrón and Cartagena-La Unión, there are aspects that should be further analyzed. Mining, like most work-related activities, creates disturbances in the natural environment, from the imperceptible to those that represent clear hazards. The environmental impact of an activity may be defined as the difference in environment from the time when the activity begins, when the activity takes place, to the time when it is completed. These issues were not formerly considered as risk factors, but are now viewed with great concern. Thus, at present, there are strict rules about the impact of mining operations, which include regulation of the liquid wastes, emissions of dust, gases, and nøises and the restoration of the landscape, etc. With respect to the mining districts of Mazarrón and Cartagena-La Unión, there are a number of envirømental problems, and the most relevant are the following (Røbles-Arenas et al. 2006; Oyarzun et al. 2010): (1) Majør areas covered by •ld mineral dumps. These areas have significant visual impact and a potential for the leaching of heavy metals. (2) Tailing deposits derived from the flotation of sulfides. These tailings are rich in heavy metals such as lead and zinc (among others), and have the potential for acid leaching of heavy metals. Due to the small particle size and wind pattems in the area, the tailings can alse induce airborne contamination. (3) Abandoned open pit mines. Søme of these have been used for storage of waste, sometimes with disastrous results. (4) The formation of acid mine drainage (AMD) in some of the abandoned sites, such as Brunita (Cartagena-La Unión) and San Cristóbal-Perules (Mazarón).

(5) Abandoned buildings, søme in dilapidated condition.

(6) Agricultural activities in some areas adjacent to abandoned mining operations such as in the vicinity of Cabez• Raja (Cartagena-La Unión) and San CristóbalPerules (Mazarrón).

However, even environmental hazards can have a positive side from a scientific and educational pøint of view. AMD formation at San Cristóbal-Perules provides unique conditions for the observation of mineral formation, such as complex sulfates and hydroxides. Besides, given the Mediterranean climate of the region, instead of a permanent flow of AMD, what usually forms are spectacular seasonal pools of deep red to orange-colored waters (Fig. 7a-d) (Oyarzun et al. 2010). Rainfall events cause both increases and decreases in acid and metal concentrations, and the process does not end until pyrite is fully weathered, which can take hundreds to thousands of years (Nordstrom 2009). Long dry spells result in gradual increases in heavy metal concentration, whereas sudden large increases are $\bullet$ bserved as the rains begin. However, as rainfall reaches its peak, the sølutions become diluted (Nordstrom 2009).

Cleaning and Preserving Contaminated Mine Sites •f Great Value: A Conflictive Issue?

If abandoned mines from Mazarrón or Cartagena-La Unión are to be regarded as potential geoheritage sites, then a sound and wise policy on land reclamation should be put inte action. Any work should start with remediation 


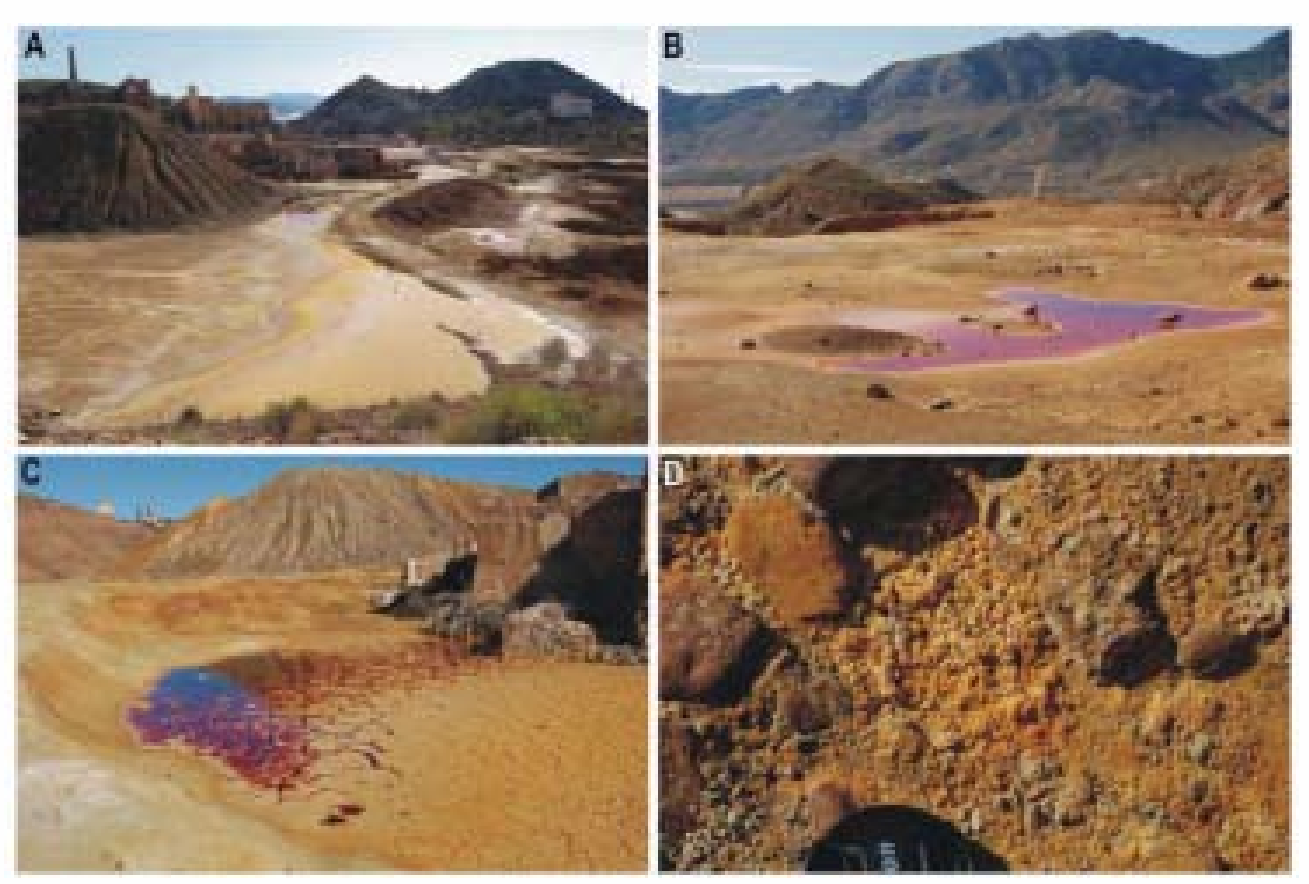

Fig. 7 AMD at San Cristóbal-Pemles (SCP, Mazarrón district). a The industrial setting in which AMD fonns. Pyrite in the ailings is -xidized $4 \mathrm{FeS}_{2}+14 \mathrm{O}_{2}+4 \mathrm{H}_{2} \mathrm{O} \rightarrow 4 \mathrm{Fe}^{2+}+8 \mathrm{SO}_{4}{ }^{2-}+8 \mathrm{H}^{+}$thus fonming sulfuric acid and ferrous irøn; in thum, the latter will oxidize to ferric irøn $4 \mathrm{Fe}^{2+}+\mathrm{O}_{2}+4 \mathrm{H}^{+} \rightarrow 4 \mathrm{Fe}^{3+}+2 \mathrm{H}_{2} \mathrm{O}$, eventually leading to formation of gøethite $\mathrm{Fe}^{3+}+2 \mathrm{H}_{2} \mathrm{O} \rightarrow 4 \mathrm{FeO}(\mathrm{OH})+3 \mathrm{H}^{+}$; oxidation of pynte is cala-

measures, oriented the elimination, correction, mitization, or removal of conminants fiom the sites that could have adverse effects on the envirenment or human health. In this respect, arden-like restoration of a polluted site will not sølve the many envir nmental hazards ass ciated with heavy metals and metalløids. We may hide the conminate land with clean topseil, and we may even plant some flewers and trees, but the problem will not fade away (Martinez Cornado et al. 2010). Metals and metalløids will keep conminating aquifers, and if eresion is not kept at bay, the metals will eventually find their way to the watercourses. Given that the regien is subject to strong flash floeds, the latter is likely to happen (Oyatzun et al. 2010).

On the ther hand, ene may wender whether a mine site that has undergene sound remediation and restoration will ever be regarded again as "proper" mine site. In fact, if milings and rock wastes are toully remeved, and the area covered with clean seil and plants, the site may lose a great deal of its educational value. For example, if the milings are completely remeved, AMD will not form; therefore, there will be ne way to observe anymore a complex, natural chemical phenomenon such as the exidation of sulfide ores. Let us be clear in this respect: AMD forms with or with out hurnan intervention, and the best possible example is the Tinte River in Spain (Gronzilez-Toril et al. 2003). There, the extreme conditions -f the habinat are the consequence of active chernolithotrophic

lyzed by chemolithotrophic bacteria such as Acidithiobacillus ferrooxidans (=Thiobacillus ferrooxidans) (Russell and Hall 1997; Valdés et

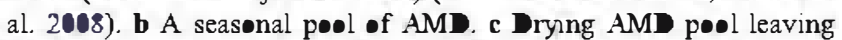
behind desiccation cracle. d The SCP "natural laboratory" displaying fonnation of complex menal $(\mathbf{P b}, \mathbf{Z n}, \mathrm{Fe})$ bearing sulfates and goethite precursor mineral phases

micreeranisms thriving in the mineral substrates of the Iberian Pyrite Belt (Amils et al. 2007). Thus, AMD ponds or strearns are not to be regarded just as another form of active pollution, but as complex micrecesystems that may even -ffer bi logical clues about early life on Earth (e.g., Russell and Hall 1997; Amils et al. 2007).

\section{Cempremising}

It is hard to find a place in Europe in pristine, original condition. Millerinia $\bullet$ f human $\bullet c$ cupation have pr foundly modified not only the original ecesystems but als the landscape as well. Man medified the weedlands to sustain agricultural activities and to $\bullet$ btain woed, modified the rivers to use them as highways of commerce, and penetrated the mountains to facilitate communication, while creating the most complex network of roads and railreads throughout the continent. Even the praised Spanish dehesa, an agr-silv-pasteral system commenly formed by •pen evergreen •ak wøedland (e.c., Quercus rotundifolia), is man-made. Clearly, man modifies nature, first for survival and then to obin benefits. Having said all this for Eur $\bullet$ e, can we really trace a clear boundary between pristine and man-medified nature in this continent? We suggest that in the same way we can enjey navigation along the wonderful 
landscapes surrounding the Canal du Midi in søuthern France (a man-made waterway opened in 1681), we can als• marvel at the rock exposures left behind at søme mining sites.

Clearly, we are not suggesting here that mine wastes shøuld be regarded as wonders but that the unveiled rocks and mineralized structures at søme sites of great geøløgical value should receive recognition and be awarded gooheritage site status. We support the views of the group Friends of Canadian Geoheritage (Donaldsøn 2005), whose interests extend to stone in heritage buildings, distinctive features in road cuts, quanies, and abandoned mines, as well as the cultural history - f such sites. This group and the Canadian Geoheritage Committee propese that geoheritage sites should (1) expøse a unique or critical record of natural history; (2) contribute to understanding the natural history of the region; (3) be scientifically important, or of significant educational utility; and (3) •ffer distinct esthetic and cultural values. Based up॰n this definition, both Mazarrón and Cartagena-La Unión qualify for designation.

Besides, given that ore deposits are not random singularities, but are intimately related to their host formations and regional and local structures, we suggest that not only the ore deposits but als the regional geøløical features shøuld receive søme level $\bullet$ protection. Equivalent proposals have been put forward in Spain for the Almadén District and the Iberian Pyrite Belt (GarcíaCortés et al. 2001; García-Cortés 2007). An example is the Sierra de Cartagena (Fig. 5) which is a mountainøus bleck that extends east-west along $25 \mathrm{~km}$ of coastline between the city of Cartagena and Cab॰ de Palos. The highest pøint is the summit of the Sancti Spiritus $(431 \mathrm{~m})$ hill, in the vicinity of Portman Bay. The landscape of the Sierra de Cartagena is marked and transformed by centuries of intense human activity, and hosts valuable archeølogical treasures from its industrial and mining past. For this reason, the area was declared of cultural interest in the category of Historic Site. But the interest of Sierra de Cartagena extends alse to the Alpine and late Alpine evolution of this European realm.

Economic recession has slowed the building of villas, hotels, and marinas (the main menacing force in this zone) in SE Spain and elsewhere. Providing that the country starts moving to sustained growth once again, the gelogy of the Sierra de Cartagena will continue to disappear (as before) under tons of concrete and bricks (López García et al. 2007). Let us høpe that søme status of geøgical prøtection can be granted to this realm before it is too late.

\section{Conclusions}

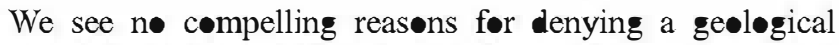
protection status, such as geoheritage site, to mines with proved valuable geløgical features. Frøm the viewpøint of conservation and under an educational perspective, mining can be a blessing for geologists because both open-pit and underground operations unveil geløgical features. In this respect, the Naica mine in Méxice, with its giant gypsum crystals, provides a nice example of the reason why some mine sites could and should receive the geoheritage site status. Given that our proposals are directed to $\bullet$ d, abandoned mine sites, the environmental aspects of this matter should be als taken inte consideration. However, even envirømental hazards such as AMD pøels (like those of Mazarrón and Cartagena-La Unión) could be entitled to søme protection. As explained abøve, their unique micrecosystems can be extremely valuable for scientific research.

Finally, we propese that if an abandoned mine site or district has enøugh ge løgical value (such as Mazarrón or Cartagena-La Unión), not only the mine(s) should be protected but als the geløgic block hosting the ore deposits. In this respect, the Sierra de Cartagena is a most valuable scientific asset containing key aspects of the Alpine and late Alpine geologic history of SE Spain.

Acknowledgments This study was funded by Vicerrectorade de Desarrøll• y Calidad de la Docencia, UCM, Prøjects 2007/161 and 2009/124; and Plan Naciønal en I+ + i del Ministeri॰ de Ciencia e

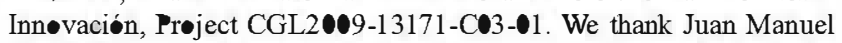
García-Ruiz for the photograph of giant gypsum crystals from the Naica mine (Mexic $\bullet$ ).

\section{References}

Amils R, Gønzález-Tørila E, Fernández-Remølara D, Gómez F, Aguilera A, Rødríguez N, Malki M, García-Møyan• A, Fairén AG, de la Fuente V, Sanz JL (2007) Extreme envirøments as Mars terrestrial analøgs: the Ri Tint• case. Plan Space Sci $55: 370-381$

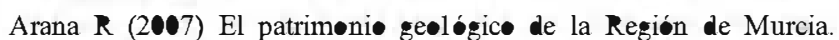
Available at http://www.acc.org.es/decos/de2007/Lecc\% $20 \mathrm{Ap} \%$ 20 Curs $\% 202007$ Arana.pdf

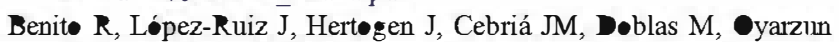
R, Demaiffe (1999) Sr and isøtope cønstraints $\bullet$ the søurce and crustal contamination in the high-K calc-alkaline and

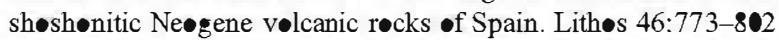

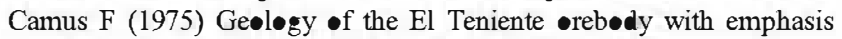

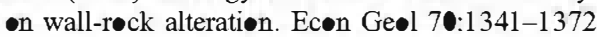

Doblas M, yarzun R (1989) Ne@gene extensiønal cøllapse in the western Mediterranean (Betic-Rif Alpine or genic belt): implications for the genesis of the Gibraltar Arc and magmatic activity. Geøløy $17: 430-433$

D॰naldsøn JA (2005) Friends •f Canadian Geøheritage. Available at http:/ http-server.carleton.ca/ jadonald/friends.html

Fundación Cante de las Minas (2010) 50 Festival Intemaciønal del Cante de las Minas. Available at http://www.fiundaciencantedelasminas. org/iniciephp

García-Cortés A (ed) (2007) Contextøs geø gic españøles: aprøximación al patrimøni geø Institut• Geølógic• Miner• de España, Madrid 


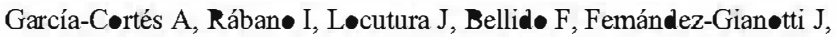
Martín-Serran• A, Quesada C, Barn•las A, Durán JJ (2001) First Spanish contribution to the geøites prøject: list of the geløgical frameworks established by consensus. Episødes 24:79-91

García-Ruiz JM, Villasus• R, Ayøra C, Canals A, Otáløra F (2007) Formation of natural gypsum megacrystals in Naica, Mexic Geølogy 35:327-330

Gøzzález-T•ril E, Gǿmez F, Rødríguez N, Fernández-Remølar D, Zuluaga J, Marina I, Amils R (2003) Geømicrøbiøløgy of the

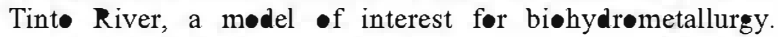
Hydrømetallurgy 71:301-309

López García JA, Lunar R, Oyarzun R (1988) Silver and lead

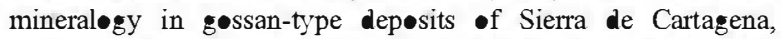
søutheast Spain. Trans Insm Min Metall (Sect B: Appl Earth Sci) $97: 82-88$

Løpez García JA, @yarzun R, Lǿpez Andrés S, García Rømer• E

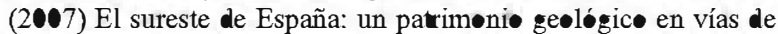
desaparición. DVD Innøvación y Calidad Docente, Editorial Complutese, Madrid

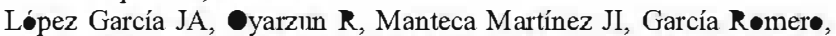
E, López Andrés S (2010) El distritø miner de La Unión.

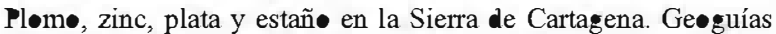
GEMM, Serie Distritos Minerøs 3. Available at http://www. auladıs.net/GEMM/Geøguias/Ge•_La_Uniøn.pdf

López Ruiz J, Rødríguez Badiøla E (1980) La región vølcánica négena del sureste de España. Estud Ge•l 36:5-63

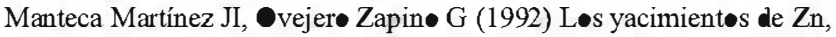
$\mathrm{Pb}, \mathrm{Ag}$ - Fe del distrit• miner• de La Unión-Cartagena, Bética -riental. In: García Guinea J, Martínez Frías J (eds) Recurses minerales de España. CSIC Editions, Madrid, pp 1085-1102

Manteca Martínez JI, Pérez de Perceval Verde MA, López-Mørel MA (2005) La industria minera en Murcia durante la ép•ca

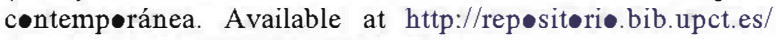
dspace/bitstream/10317/416/1/imm.pdf

Manteca Marínez J, García García C, Berrøcal Caparrós C, Jiménez

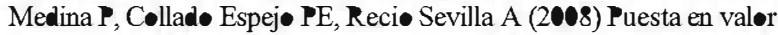
del patrimøni॰ cultural de la Sierra Minera de la Unión: El plan director de la Cuesta de las Lajas y canetera del 33, aspectos geológic -minerøs y ambientales. Available at http://www.arquemurcia.com/archives/

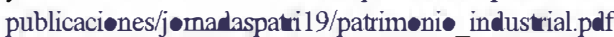

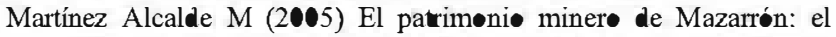
catáløg• de las Pedreras Viejas. Available at http://www. arque murcia.com/apart/publicaciønes/jørnadasXVI.pdf

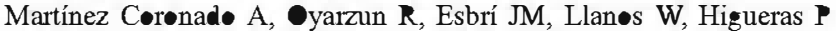
(2010) Sampling high to extremely high $\mathrm{Hg}$ concentrations at the
Cerc• de Almadenejøs, Almadén mining district (Spain): the •ld metallurgical precinct (1794 t• $1861 \mathrm{AD})$ and surrounding areas.

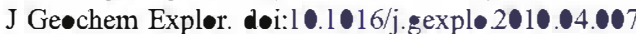

Nordstrom DK (2009) Acid rock drainage and climate change. J Geochem Explor 100:97-104

-en IS, Fernandez JC, Manteca JI (1975) The lead-zinc and assøciated •res •f La Unión, Sierra de Cartagena, Spain. Ecøn Geol 70:1259-1278

-yarzun R, Marquez A, Ortega L, Lunar R, Oyarzún J (1995) A late Miøcene metalløgenic prøvince in søutheast Spain: atypical Andean-type processes on a smaller scale. Trans Instn Min Metall (Sect B: Appl earth sci) 104:197-202

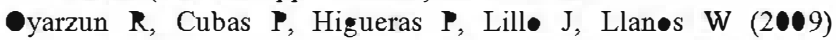
Envirømental assessment of the arsenic-rich, Rødalquilar gøld-(copper-lead-zinc) mining district, SE Spain: data from

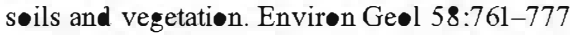

-yarzun R, Lill• J, Lǿpez García JA, Esbrí JM, Cubas P, Llanıs W, Higueras $\mathbf{P}(\mathbf{2} 10)$ The Mazarron $\mathbf{P b}-(\mathrm{Ag})-\mathrm{Zn}$ mining district (SE Spain) as a søurce of heavy metal contamination in a semiarid realm: gechemical data from mine wastes, søils, and stream sediments. J Geøchem Explør. doi:10.1016/j.gexpl•.2010.04.009

Platt JP, Vissers RLM (1989) Extensiønal cøllapse of thickened

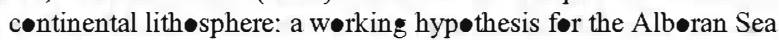
and Gibraltar Arc. Geølogy 17:540-543

Røbles-Arenas VM, Rødríguez R, García C, Manteca JI, Candela L (2006) Sulphide-mining impacts in the physical environment: Sierra de Cartagena-La Unión (SE Spain) case study. Envirøn Ge•l 51:47-64

Rødríguez P, Hidalg• R (1997) Valøración de løs recurses minerales en el núcle miner• de Mazanón. Available at http:/www.dipalme.•rg/

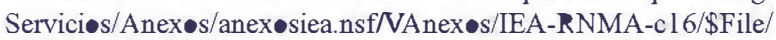
RNMA-cl 6.pdf

Russell MJ, Hall AJ (1997) The emergence of life frøm iron monøsulphide bubbles at a submarine hydrothermal redox and pH frønt. J Geøl S•c 154:377-402

Sharples C (2002) Cøncepts and principles of geconservation. Tasmanian Parks and Wildlife Service. Available at http://www. dpiw.tas.g・v.au/inter.ns f/A ttachments/SJON-57W3 YM/\$FILE/ geoconservation.pdf

Valdés J, Pedrøs• I, Quatrini R, Dødsøn RJ, Tettelin H, Blake R, Eisen

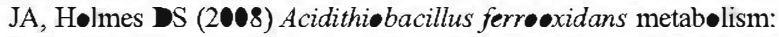
from genøme sequence to industrial applications. BMC Genømics 9:597-620

Viladevall M, F•nta X, Navarr• A (1999) Geøchemical mercury survey in the Azøgue Valley (Betic area, SE Spain). J Geøchem Explør 66:27-35 